\title{
Evaluation of the melting temperature of TaqMan probes as a genotyping method for IDH1, IDH2, and H3F3A in pediatric astrocytomas
}

\author{
Aranxa Torres-Caballero ${ }^{1}$, Amarantha Serrato ${ }^{1}$, Tayde López-Santaella ${ }^{1}$, Rosario Ortiz², \\ Fernando Chico-Ponce de León ${ }^{3}$, Vicente González-Carranza ${ }^{3}$, Samuel Torres-García ${ }^{3}$, \\ Francisco Arenas-Huertero ${ }^{4}$, and Abrahan Hernández-Hernández ${ }^{1,4 *}$ \\ ${ }^{1}$ Unidad de Biología de Células Individuales, Hospital Infantil de México Federico Gómez; '2Laboratorio de Microscopía Electrónica, Facultad de \\ Ciencias, Universidad Nacional Autónoma de México; ${ }^{3}$ Departamento de Neurología, Hospital Infantil de México Federico Gómez; ${ }^{4}$ Laboratorio de \\ Investigación en Patología Experimental, Hospital Infantil de México Federico Gómez. Mexico City, Mexico
}

\begin{abstract}
Background: Astrocytomas are cancer tumors of the central nervous system and represent the most common type of solid tumors during human childhood. In 2016, the World Health Organization established a molecular classification system to regroup tumor entities to achieve a more accurate diagnosis and a better clinical decision-making and selection of treatment in patients with these types of tumors. Methods: We evaluated a genotyping assay for rapid and cost-effective mutation detection in astrocytomas using TaqMan probes in an asymmetric polymerase chain reaction (PCR) assay. Results: Four diffuse astrocytomas (Grade II), three anaplastic astrocytomas (Grade III), and four glioblastomas (Grade IV) were sequenced, and all of them displayed the wild-type (WT) sequence. We tried to set up this melting analysis for the genotyping of pediatric astrocytomas by identifying the specific melting temperatures of the TaqMan probes due to the presence of the WT sequences in the isocitrate dehydrogenase 1 and 2 (IDH1 and IDH2) and H3.3 histone A genes (H3F3A). We used an IDH1-TaqMan probe to identify the WT status of IDH1 in two different WT deoxyribonucleic acid (DNA) templates (pilocytic and diffuse astrocytoma) and obtained four melting temperature values ranged from 65.6 to $92.2^{\circ} \mathrm{C}$. Furthermore, only four out of 29 reactions displayed amplification of the DNA template. Sanger sequencing was faster and more reliable to detect the gene status in all the sequenced samples. Conclusions: We conclude that conventional Sanger sequencing remains the gold standard for the genotyping of pediatric astrocytomas.
\end{abstract}

Key words: Pediatric astrocytoma. Genotyping. Isocitrate dehydrogenase 1. Isocitrate dehydrogenase 2. H3.3 histone A.

\section{Evaluación del método de temperatura de disociación de sondas TaqMan para la genotipificación de IDH1, IDH2 y H3F3A en astrocitomas pediátricos}

\section{Resumen}

Introducción: Los astrocitomas son un tipo de cáncer que afecta al sistema nervioso central y representan el tumor sólido más común durante la infancia. En el año 2016, la Organización Mundial de la Salud estableció un sistema de clasificación molecular para reagrupar tumores con identidades genéticas similares y lograr un diagnóstico más preciso, lo que lleva a

\section{Correspondence:}

*Abrahan Hernández Hernández

E-mail: abrahan.hernandez@ @imfg.edu.mx (http://creativecommons.org/licenses/by-nc-nd/4.0/).
Date of reception: 04-04-2020

Date of acceptance: 29-06-2020

DOI: 10.24875/BMHIM.20000092
Available online: 13-11-2020

Bol Med Hosp Infant Mex. 2020;77(6):303-311

www.bmhim.com

1665-1146/@ 2020 Hospital Infantil de México Federico Gómez. Published by Permanyer. This is an open access article under the CC BY-NC-ND license 
tomar las decisiones clínicas idóneas al elegir el tratamiento de pacientes con este tipo de tumores. Métodos: Se evaluó un protocolo que involucra el uso de sondas TaqMan en un ensayo de reacción en cadena de la polimerasa asimétrica para la detección de mutaciones en astrocitomas. Se secuenciaron cuatro astrocitomas difusos (Grado II), tres astrocitomas anaplásicos (Grado III) y cuatro glioblastomas (Grado IV). Se intentó establecer las condiciones del análisis para la genotipificación de los astrocitomas pediátricos mediante la identificación de las temperaturas de disociación específicas de las sondas TaqMan producidas por la prescencia de las secuancias WT en los genes isocitrato deshidrogenasa 1 y 2 (IDH1, IDH2) y H3.3 histona A (H3F3A). Resultados: Los astrocitomas mostraron la secuencia wild type (WT) (silvestre) de los genes. Se utilizó una sonda TaqMan IDH1 para identificar el estado de este gen en dos templados WT de DNA (astrocitoma pilocítico y difuso) y se obtuvieron cuatro valores de temperatura de disociación (65.6-92.2 ${ }^{\circ} \mathrm{C}$ ). Solo cuatro de las 29 reacciones mostraron amplificación de DNA. La secuenciación de Sanger fue más rápida y confiable para detectar el estado de los genes en todas las muestras. Conclusiones: La secuenciación de Sanger sigue siendo la técnica más práctica para la genotipificación de astrocitomas pediátricos.

Palabras clave: Astrocitoma pediátrico. Genotipificación. Isocitrato deshidrogenasa 1. Isocitrato deshidrogenasa 2. H3.3 histona A.

\section{Introduction}

Tumors of the central nervous system (CNS) are the most common solid tumors during childhood and are among the top two causes of cancer-related death in children in Mexico and worldwide ${ }^{1-3}$. These brain tumors are classified according to histology and tumor location. Gliomas arise from glial precursor cells present in the brain and spinal cord and are named according to their clinicopathologic and histologic subtype: astrocytomas originate from astrocytes, oligodendroglial tumors from oligodendrocytes, and mixed gliomas from a mix of oligodendrocytes, astrocytes, and ependymal cells. Significant experimental evidence shows that neural stem cells, glial progenitor cells, oligodendrocyte progenitor cells, and possibly differentiated astrocytes can serve as cells of origin for astrocytoma ${ }^{4,5}$. This type of tumor is the most commonly diagnosed type of glioma in children ${ }^{4}$. In Mexico, $32 \%$ of the diagnosed brain tumors correspond to astrocytoma ${ }^{1-3}$.

In 2007, the World Health Organization (WHO) published a series of guidelines to grade the CNS tumors ${ }^{6}$. Thus, histopathological characteristics observed in hematoxylin- and eosin-stained sections, immunohistochemistry of lineage-associated proteins, and ultrastructural characteristics have been used for grading the pediatric astrocytomas into four grades (Table 1), leading to a lot of confusion and doubts among pathologists as the differentiation level varies between grades?

Recently, the WHO published an updated grading system that considers the genetic basis of tumorigenesis and histological features ${ }^{6,8}$. In this classification, diffuse astrocytoma, anaplastic astrocytoma, and glioblastoma are clustered in the diffuse astrocytic tumor category. Within this grading system, genetic driver mutations are included in these categories. Therefore, diffuse astrocytic tumors are further classified by the presence or absence of mutations in the isocitrate dehydrogenase 1/2 (IDH1/IDH2) (isocitrate dehydrogenase $[I D H]$ and nicotinamide adenine dinucleotide phosphate $[\mathrm{NADP}+] 1$ and 2, respectively) and $\mathrm{H} 3.3$ histone $\mathrm{A}(H 3 F 3 A)$ genes. Meanwhile, low-grade astrocytomas are grouped into the other astrocytic tumor categories (Table 1) $)^{7,9,10}$; thus, genotyping is not required as low-grade astrocytomas do not harbor these driver mutations.

The IDH1 and IDH2 proteins in the cytosol and mitochondria generate reduced NADPH from NADP+ by catalyzing the oxidative decarboxylation of isocitrate into alpha-ketoglutarate $(\alpha-K G)$ outside of the Krebs cycle. IDH gene mutations in one allele (heterozygous mutation) produce a switch from arginine to histidine at amino acid residue $132(\mathrm{R} 132 \mathrm{H})$ that changes the function of the enzymes, which, in turn, produce 2-hydroxyglutarate, a possible oncometabolite, instead of NADPH. IDH1 mutations occur more commonly in glioma than IDH2 mutations, which undergo a similar missense mutation at arginine $172(\mathrm{R} 172 \mathrm{H})^{11-14}$.

H3F3A may bear mutations that change lysine to methionine at position 27 (K27M) or glycine to valine or arginine at position 34 (G34R/V). These two mutations, detected by whole-genome sequencing, are seen in $30 \%$ of pediatric glioblastoma. However, the incidence of these mutations increases to $95 \%$ in highgrade glioblastoma from the midline location (80 and $15 \%$ of high-grade glioblastoma bearing K27M and G34R mutation, respectively) $)^{15,16}$.

This upgraded classification system elicited a layered diagnosis with histological classification. The WHO grades with molecular information are reported as integrated diagnosis, improving diagnostic accuracy, patient management, and treatment response due to targeted 
Table 1. The WHO classification of astrocytoma $(2016)^{\mathrm{a}}$

\begin{tabular}{|c|c|c|c|c|c|c|}
\hline \multirow[t]{2}{*}{ Astrocytic tumors } & \multicolumn{4}{|c|}{ Histologic grade } & \multicolumn{2}{|l|}{2016 WHO classification } \\
\hline & I & II & III & IV & & \\
\hline Subependymal giant cell astrocytoma & $\mathrm{x}$ & & & & \multirow[t]{4}{*}{ Other astrocytic tumors } & \\
\hline Pilocytic astrocytoma & $\mathrm{X}$ & & & & & \\
\hline Pilomyxoid astrocytoma ${ }^{b}$ & & $\mathrm{X}$ & & & & \\
\hline Pleomorphic xanthoastrocytoma & & $\mathrm{X}$ & & & & \\
\hline Diffuse astrocytoma & & $\mathrm{X}$ & & & Diffuse astrocytoma, IDH-mutant & \multirow{5}{*}{$\begin{array}{l}\text { Diffuse astrocytic } \\
\text { tumors }\end{array}$} \\
\hline Anaplastic astrocytoma & & & $\mathrm{X}$ & & Anaplastic astrocytoma, IDH-mutant & \\
\hline Glioblastoma & & & & $\mathrm{x}$ & \multirow{3}{*}{$\begin{array}{l}\text { Glioblastoma, IDH-wild-type } \\
\text { Glioblastoma, IDH-mutant } \\
\text { Diffuse midline glioma, H3 K27M-mutant }\end{array}$} & \\
\hline Giant cell glioblastoma & & & & $\mathrm{X}$ & & \\
\hline Gliosarcoma & & & & $\mathrm{X}$ & & \\
\hline
\end{tabular}

WHO, World Health Organization; IDH, isocitrate dehydrogenase; H3 K27M, histone H3 K27M.

adapted from Louis et al., 2007 and $2016^{6,10}$. This integrative classification includes the grading system used by the 2007 guidelines and the genetic driving mutation incorporated in 2016. The children specific H3 K27M entity is added in the current classification system.

bIn 2016, the WHO suggested not grading the pilomyxoid variant until further studies clarify its behavior.

therapies. However, it will also impose some technological constrains as not all the diagnosis centers may have access to genetic diagnostic tools (i.e., deoxyribonucleic acid [DNA] sequencing $)^{7,8}$. Hence, it is essential to establish simple, cost-effective, and sensitive mutation scanning methods in clinical laboratories.

Sanger DNA sequencing has been widely used as the gold standard for clinical DNA analyses. However, it presents a low sensitivity $(15-20 \%$ limit of mutant allele detection), emphasizing the need for a simple, cost-effective, and sensitive methods for mutation scanning in clinical laboratories as a routine practice for tumor sample analyses. The DNA melting analysis (DMA) of TaqMan probes has been claimed to fulfill such criteria. It has been used by Botezatu et al. and Huang et al. for the identification of mutations in the phosphatidylinositol-4,5-bisphosphate 3-kinase catalytic subunit alpha (PIK3CA), KRAS (KRAS proto-oncogene GTPase), NRAS (NRAS proto-oncogene GTPase), and BRAF (B-Raf proto-oncogene serine/threonine kinase) genes ${ }^{17-19}$. The theoretical basis of the method is the dependence of the melting temperature of the double DNA helix on its length, base composition (GC content), sequence, and the degree of complementarity of the strands. An increase in the fluorescence of a self-quenching fluorescence probe, like TaqMan probes, has been shown not only when it is cleaved by Taq DNA polymerase in the polymerase chain reaction
Table 2. Classification of diffuse astrocytic tumors by DNA Sanger sequencing

\begin{tabular}{|c|c|c|c|}
\hline $\begin{array}{l}\text { Astrocytoma-grade } \\
\text { (local ID) }\end{array}$ & $\begin{array}{l}\text { R132 } \\
\text { in IDH1 }\end{array}$ & $\begin{array}{l}\text { R172 } \\
\text { in IDH2 }\end{array}$ & $\begin{array}{l}\text { K27 and G34 } \\
\text { in H3F3A }\end{array}$ \\
\hline $\begin{array}{l}\text { Pilomixoid astrocytoma- } \\
\text { II (M17) }\end{array}$ & Wild type & Wild type & NA \\
\hline $\begin{array}{l}\text { Diffuse astrocytoma-II } \\
\text { (CM15) }\end{array}$ & Wild type & Wild type & NA \\
\hline $\begin{array}{l}\text { Diffuse astrocytoma-II } \\
\text { (CM39) }\end{array}$ & Wild type & Wild type & NA \\
\hline $\begin{array}{l}\text { Pilomixoid astrocytoma- } \\
\text { II (CM75) }\end{array}$ & Wild type & Wild type & NA \\
\hline $\begin{array}{l}\text { Anaplastic astrocytoma- } \\
\text { III (M29) }\end{array}$ & Wild type & Wild type & NA \\
\hline $\begin{array}{l}\text { Anaplastic astrocytoma- } \\
\text { III (CM54) }\end{array}$ & Wild type & Wild type & NA \\
\hline $\begin{array}{l}\text { Anaplastic astrocytoma- } \\
\text { III (M69) }\end{array}$ & Wild type & Wild type & NA \\
\hline Glioblastoma-IV (M9) & Wild type & Wild type & Wild type \\
\hline Glioblastoma-IV (M10) & Wild type & Wild type & Wild type \\
\hline Glioblastoma-IV (M49) & Wild type & Wild type & Wild type \\
\hline Glioblastoma-IV (CM8) & Wild type & Wild type & Wild type \\
\hline
\end{tabular}

Tumor biopsies were classified by the Pathology Department of the Hospital Infantil de México Federico Gómez using genotyping by Sanger sequencing. The codons used for genotyping of $I D H 1, I D H 2$, and $H 3 F 3 A$ and their genetic status in the tumor biopsies are displayed in single table columns.

ID, identification; NA, not applicable (as the genetic status is not used for classification); $I D H 1$, isocitrate dehydrogenase 1; IDH2, isocitrate dehydrogenase 2. H3F3A, H3.3 histone A; DNA, deoxyribonucleic acid. 


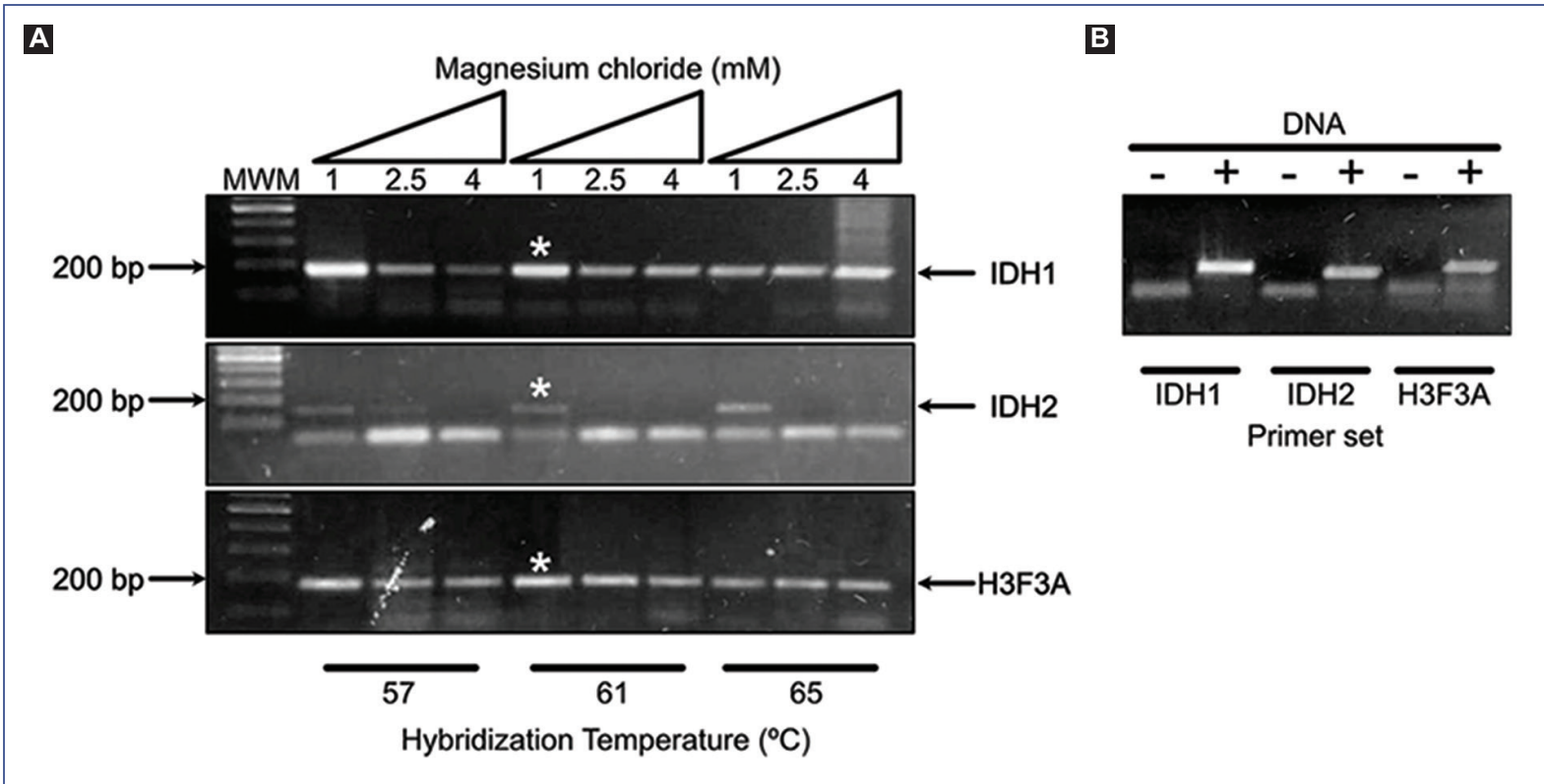

Figure 1. A: PCR standardization with magnesium chloride and hybridization temperature gradients. The PCR parameters of $1 \mathrm{mM} \mathrm{MgCl}$ and $61^{\circ} \mathrm{C}$ displayed specific amplification of the desired amplicons in IDH1, IDH2, and H3F3A genes (asterisks). B: The specificity of the PCR primers when using DNA as a template, as negative control reactions (with no DNA) were included for each amplicon. MWM: molecular weight marker; PCR: polymerase chain reaction; IDH1: isocitrate dehydrogenase 1; IDH2: isocitrate dehydrogenase 2; H3F3A: H3.3 histone A; DNA: deoxyribonucleic acid.

(PCR) but also when it is hybridized with the DNA used as a template (in both cases, the fluorophore and the quencher became spatially separated) $)^{18,20}$. Therefore, the TaqMan probe dissociation from a non-mutated (KO) or WT DNA will produce a specific melting temperature that can be scored by the drop of fluorescence (as the fluorophore and the quencher become more prone to contact each other upon dissociation from the template DNA). Meanwhile, the presence of a single mutation in the template DNA will produce a shift of this melting temperature.

Therefore, the analysis of the melting temperature of a TaqMan probe can be used to identify the WT or KO status of the genes of interest. In addition, this assay allows using TaqMan probes in a closed-tube format, first performing asymmetric PCR by adding more concentration either of the forward or reverse primer (to accumulate single-stranded DNA) and then the analysis of the melting temperature of the TaqMan probes ${ }^{17-19}$.

To incorporate a molecular classification system that enables a more precise tumor classification as suggested by the WHO in 2016, we have evaluated the genotyping of pediatric astrocytomas with the DMA of TaqMan probes coupled to asymmetric PCR.

\section{Methods}

\section{DNA isolation}

Astrocytoma biopsies were obtained from the Neurosurgery Department of the Hospital Infantil de Mexico Federico Gomez under the informed consent of patients and their parents. All the experimental procedures have been approved by the scientific, ethical, and biosafety committees of the hospital (project numbers HIM/2017/104/SSA-1420 and HIM/2016/096/SSA-1289). Template DNA was isolated from brain tumor samples described in table 2 using the AllPrep DNA/RNA/ miRNA Universal Kit (QIAGEN). DNA concentration and integrity were evaluated with the NanoDrop system (Thermo Scientific). Only DNA samples with high quality were used for both the DMA-TaqMan method and Sanger sequencing.

\section{Primer and TaqMan probe design}

To design primers pairs and TaqMan probes, we followed previous reports ${ }^{17-19}$. Briefly, three primer pairs for the IDH1, IDH2, and H3F3A genes (from the Human genes hg38 assembly, in the UCSC Genome Browser ${ }^{21}$ ) 
Table 3. Primers and probes used for mutation scanning by dissociation curve

\begin{tabular}{|c|c|c|c|}
\hline $\begin{array}{l}\text { Genomic sequence } \\
\text { to be amplified }\end{array}$ & $\begin{array}{l}\text { Codon with a } \\
\text { mutation to be } \\
\text { detected }\end{array}$ & $\begin{array}{l}\text { Forward (F) and reverse ( } R \text { ) primers } \\
\left(T_{m} \text { and } C G \%\right) \\
\text { Sense (s) or antisense (as) Taqman probes }\end{array}$ & Sequence \\
\hline \multirow[t]{3}{*}{$\begin{array}{l}180 \mathrm{bp} \text { in exon } 2 \\
\text { and intron } 2 \text { in } I D H 1\end{array}$} & \multirow[t]{3}{*}{ R132 } & $\begin{array}{l}\text { IDH1-F } \\
\left(59^{\circ} \mathrm{C}, 55 \%\right)\end{array}$ & $5^{\prime}$ atattctgggtggcacggtc $3^{\prime}$ \\
\hline & & $\begin{array}{l}\text { IDH1-R } \\
\left(58^{\circ} \mathrm{C}, 41 \%\right)\end{array}$ & $5^{\prime}$ aagttggaaatttctgggccat $3^{\prime}$ \\
\hline & & Probe IDH1 (as) & [FAM]ccataagcatgacgacctatgatgat[BHQ-1] \\
\hline \multirow[t]{3}{*}{$\begin{array}{l}152 \mathrm{bp} \text { in exon } 4 \\
\text { and intron } 4 \text { in } I D H 2\end{array}$} & \multirow[t]{3}{*}{ R172 } & $\begin{array}{l}\text { IDH2-F } \\
\left(59^{\circ} \mathrm{C}, 50 \%\right)\end{array}$ & $5^{\prime}$ tctgcaaaaacatcccacgc $3^{\prime}$ \\
\hline & & $\begin{array}{l}\text { IDH2-R } \\
\left(59^{\circ} \mathrm{C}, 60 \%\right)\end{array}$ & $5^{\prime}$ caagaggatggctaggcgag $3^{\prime}$ \\
\hline & & Probe IDH2 (s) & [TAMRA] atcaccattggcaggcacgcccatgg[BHQ-2] \\
\hline \multirow[t]{4}{*}{$\begin{array}{l}180 \text { bp in exon } 1 \text { in } \\
\text { H3F3A }\end{array}$} & \multirow[t]{4}{*}{ K27 and G34 } & $\begin{array}{l}H 3 F 3 A-F \\
\left(59^{\circ} \mathrm{C}, 50 \%\right)\end{array}$ & $5^{\prime}$ tggctcgtacaaagcagact $3^{\prime}$ \\
\hline & & $\begin{array}{l}H 3 F 3 A-R \\
\left(55^{\circ} \mathrm{C}, 36 \%\right)\end{array}$ & $5^{\prime}$ tgtggatacatacaagagagacttt $3^{\prime}$ \\
\hline & & Probe $H 3 F 3 A, K 27$ (as) & [Cy5]agggcgcactcttgcgagcggctttt[BHO-3] \\
\hline & & Probe $H 3 F 3 A, G 34$ (s) & [HEX]gcgccctctactggaggggtgaagaa[BHQ-1] \\
\hline
\end{tabular}

Specific primers were designed to amplify three genomic regions (in $I D H 1, I D H 2$, and $H 3 F 3 A$ genes) that bear possible mutations, as well as long TaqMan probes for each amplicon. Each TaqMan has different fluorophores plus their specific signal quenchers. The same primers were used for the DNA melting analysis (DMA)-TaqMan method and Sanger sequencing.

$\mathrm{T}_{\mathrm{m}}$, melting temperature; GC\%, guanine-cytosine content; bp, base pairs; IDH1, isocitrate dehydrogenase 1; IDH2, isocitrate dehydrogenase 2; H3F3A, H3.3 histone $\mathrm{A}$; FAM: carboxyfluorescein; BHQ: black hole quencher ${ }^{\mathrm{TM}}$ family; TAMRA: carboxytetramethylrhodamine; Cy5: cyanine-5; HEX: hexachlorofluorescein phosphoramidite

were designed using the Primer-Blast tool ${ }^{22}$. In addition, a TaqMan probe for each amplified gene segment was designed to have the nucleotide matching the possible mutation in the middle of the probe (Table 3). The same primers were used for the DMA of the TaqMan probes method and Sanger sequencing.

\section{PCR}

To set up PCR conditions for specific amplification of the desired regions, we performed PCRs with magnesium chloride and hybridization temperature gradients. We detected specific amplification parameters of the three amplicons under $1 \mathrm{mM} \mathrm{MgCl} 2$ and $61^{\circ} \mathrm{C}$ (Fig. 1A).

The specificity of the PCR primers was verified with the next reactions and settings: each $20 \mu \mathrm{l}$ volume reaction contained $1 \mathrm{x}$ amplification buffer, $10 \mathrm{mM}$ dNTPs, 1 $\mathrm{mM} \mathrm{MgCl}{ }_{2}, 1 \cup$ Taq DNA polymerase (Thermo Scientific), a primer pair (0.5 $\mu \mathrm{M}$ each one), and $50 \mathrm{ng}$ of DNA template. The PCR protocol started with a denaturation step for $3 \mathrm{~min}$ at $95^{\circ} \mathrm{C}$, followed by 45 cycles at $95^{\circ} \mathrm{C}$ for $30 \mathrm{~s}, 61^{\circ} \mathrm{C}$ for $30 \mathrm{~s}$, and $72^{\circ} \mathrm{C}$ for $20 \mathrm{~s}$, with a final cycle at $72^{\circ} \mathrm{C}$ for $10 \mathrm{~min}$. PCR reactions with no DNA were included for each amplicon as negative controls (Fig. 1B).

\section{DMA of TaqMan probes in asymmetric PCR}

Each $25 \mu \mathrm{l}$ volume reaction contained $1 \mathrm{x}$ reaction buffer, $200 \mu \mathrm{M}$ dNTPs, $1 \mathrm{mM} \mathrm{MgCl}$, 1 U Taq DNA polymerase (Thermo Scientific), $0.2 \mu \mathrm{M}$ TaqMan probe, 500 ng of DNA template, and pair of specific primers with a 10 -fold concentration difference of one of the primers $(0.04 \mu \mathrm{M} / 0.4 \mu \mathrm{M})$. Real-time PCR protocol started with a denaturation step for $3 \mathrm{~min}$ at $95^{\circ} \mathrm{C}$, followed by 55 cycles at $95^{\circ} \mathrm{C}$ for $30 \mathrm{~s}, 61^{\circ} \mathrm{C}$ for $30 \mathrm{~s}$, and $72^{\circ} \mathrm{C}$ for 20 $\mathrm{s}$, and fluorescence acquisition at $62^{\circ} \mathrm{C}$. The MxProMx3000P software (version 4) was used to collect and analyze amplification and melting data from the Stratagene Mx3005P real-time PCR detection system (Agilent Technologies).

\section{Sanger sequencing and alignment of sequences}

DNA regions to be sequenced were amplified using the same primers described in table 3. PCR reactions 


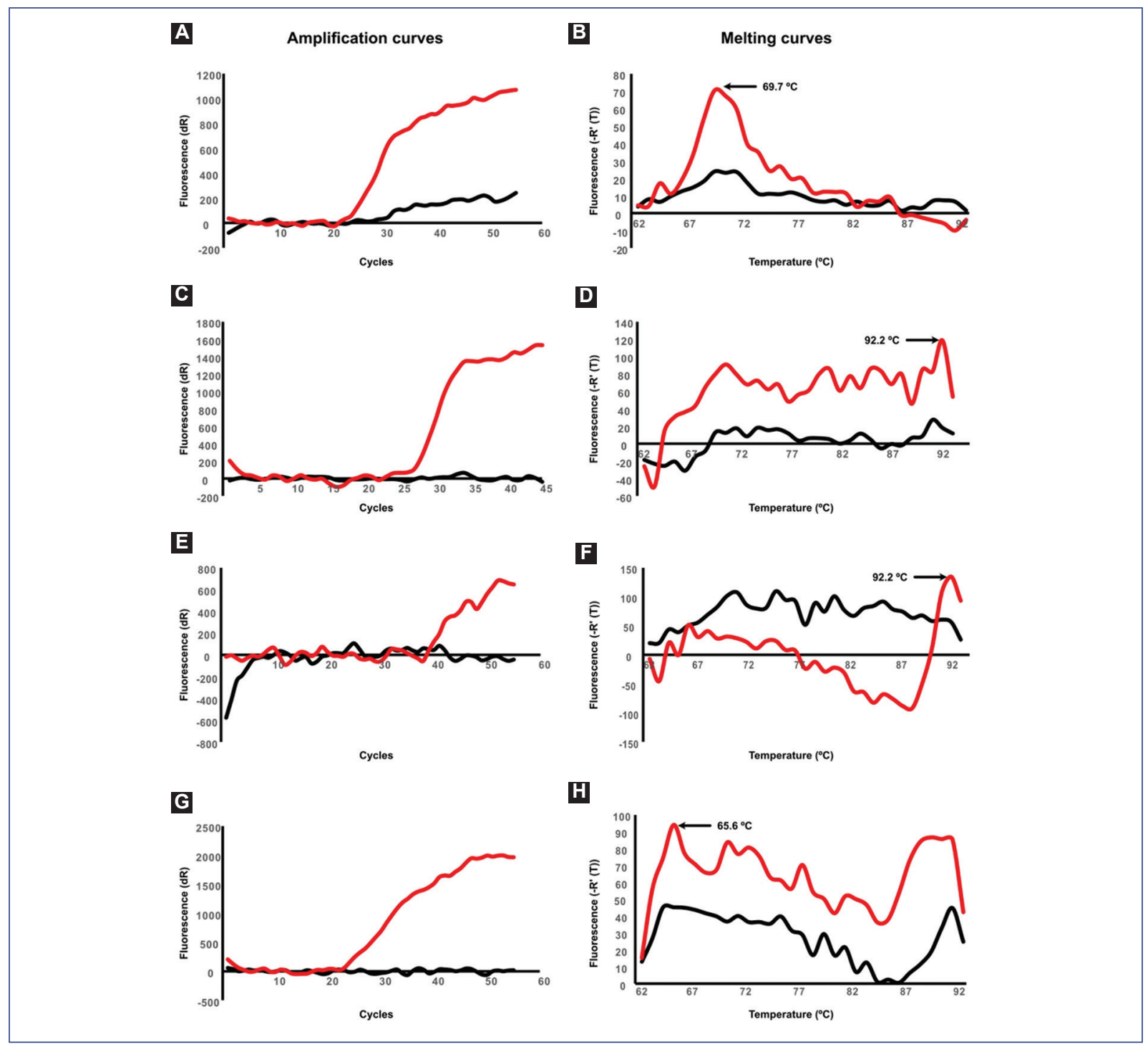

Figure 2. A, C, E, G: Amplification curves. B, D, F, H: Negative derivative melting curves for four different asymmetric PCRs. Specific primers and TaqMan probe for IDH1 (displayed in Table 2) were used to evaluate the melting curves of four different wild-type samples. The red lines indicate the fluorescence of the TaqMan probe during amplification and melting curve assessment. Peaks and values of the melting curves are displayed in each one of the respective panels. NTCs are shown in black lines. PCR: polymerase chain reaction; IDH1: isocitrate dehydrogenase 1; NTC: non-template controls.

with specific amplification of the desired amplicons were purified with the MinElute PCR Purification Kit (QIAGEN). We used $20 \mu \mathrm{l}$ of purified PCR reactions and $5 \mu \mathrm{l}$ of the specific primer $(10 \mu \mathrm{M})$ for Sanger sequencing at the Sequencing Core Facility (INMEGEN, Mexico). Sequencing results were delivered after 2 days. All the sequenced samples displayed enough quality for subsequent alignment (Table 2). To detect KO or WT DNA sequences, we performed a pairwise sequence alignment ${ }^{23}$ between the respective reference DNA (Table 3) and the sequence retrieved from Sanger sequencing.

\section{Results}

\section{Genotyping of IDH1, IDH2, and H3K27M/ G34 by Sanger sequencing}

With the primers described in table 3 , we amplified and purified the regions of interest and sequenced them by Sanger technology. Four diffuse astrocytomas (Grade II), three anaplastic astrocytomas (Grade III), and four glioblastomas (Grade IV) were sequenced, and all of them displayed the WT sequence for all the tested genes (Table 2). 
Table 4. DNA melting analysis (DMA) of TaqMan probes with asymmetric PCR

\begin{tabular}{|c|c|c|c|}
\hline Tested codon & Predicted T $\left({ }^{\circ} \mathrm{C}\right)$ & Observed $\operatorname{Tm}\left({ }^{\circ} \mathrm{C}\right)$ & Success ratio for asymmetric PCR (success/trials) \\
\hline \multirow[t]{2}{*}{$\mathrm{R} 132$ in $I D H 1$} & WT: 63.7 & $\begin{array}{c}69.7^{*} \\
92.2^{*} \\
92.2^{*} \\
65.6^{* *}\end{array}$ & $14 \%(4 / 29)$ \\
\hline & K0: 61.9 & NA & NA \\
\hline \multirow[t]{2}{*}{$\mathrm{R} 172 \mathrm{in} I D H 2$} & WT: 74.5 & NO & $0 \%(0 / 7)$ \\
\hline & KO: 72.4 & NA & NA \\
\hline \multirow[t]{4}{*}{$\mathrm{K} 27$ and $\mathrm{G} 34$ in $\mathrm{H} 3 \mathrm{~F} 3 \mathrm{~A}$} & K27-WT: 76 & NO & $0 \%(0 / 7)$ \\
\hline & K27-K0: 76.1 & NA & NA \\
\hline & G34-WT: 72.4 & NO & $0 \%(0 / 5)$ \\
\hline & G34-K0: 70.4 & NA & NA \\
\hline
\end{tabular}

Predicted and observed melting temperatures of the gene-specific TaqMan probes for IDH1, IDH2, and H3F3A genes. Information on biological replicates and the success ratio is also displayed.

NO, not observed (no data was obtained); NA, not assessed; IDH1, isocitrate dehydrogenase 1; IDH2, isocitrate dehydrogenase 2; H3F3A, H3.3 histone A; PCR, polymerase chain reaction; $\mathrm{T}_{\mathrm{m}}$ melting temperature; $\mathrm{WT}$, wild type; $\mathrm{KO}$, mutated.

The values correspond to the melting curve when using DNA from a pilocytic astrocytoma* or a diffuse astrocytoma**. KO biopsies have not been assessed (NA) as the variation of melting temperatures in WT samples exceeds the shift that a single mutation would produce.

Predicted melting temperatures were calculated with the melting temperature ( $\left.\mathrm{T}_{\mathrm{m}}\right)$ calculation Tool available at the Biophp.org project (http://www.biophp.org/).

A

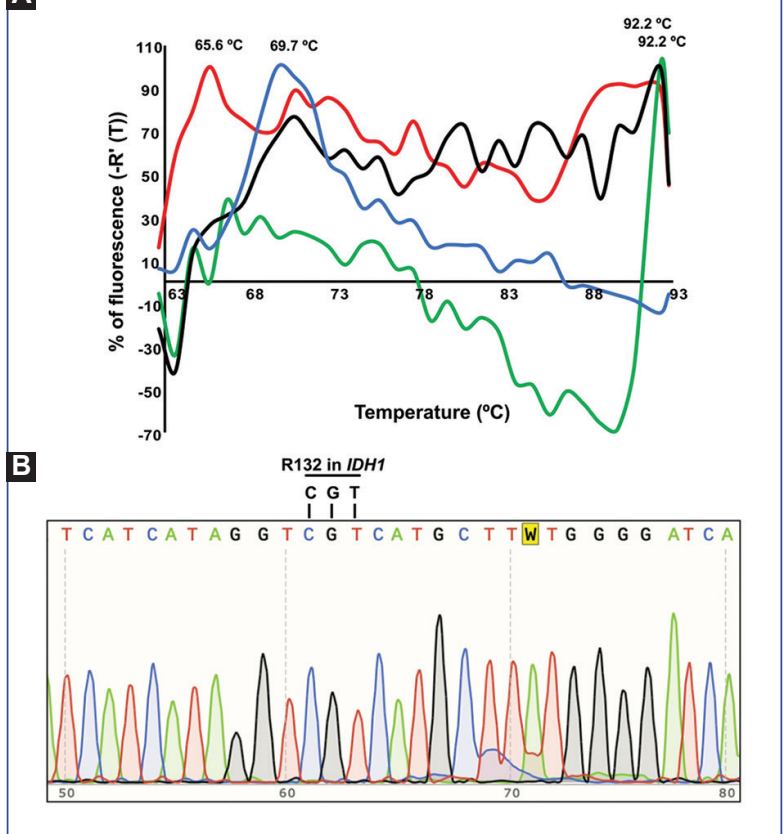

Figure 3. A: Overlapped negative derivative melting curves for four different asymmetric PCRs for the specific primers and TaqMan probe for IDH1. The negative derivate fluorescence is expressed as a percentage to make it comparable across samples. B: Chromatogram form Sanger sequencing showing the sequence of a diffuse astrocytoma IDH1-WT and its alignment to the reference sequence in the codon arginine 132 (R132). PCR: polymerase chain reaction; IDH1: isocitrate dehydrogenase 1; WT: wild type.

\section{Evaluation of DMA of the IDH1 TaqMan probe on IDH1-WT samples}

We evaluated the melting temperature of the IDH1TaqMan probe to identify the gene status of a bona fide WT template from pilocytic astrocytoma. A criterion that must be fulfilled is that the amplification of the template must be successful in order to do the melting temperature value more reliable ${ }^{19}$. Thus, we focused on melting temperature curves from $\mathrm{PCR}$ reactions that displayed amplification signals during the respective cycles of the real-time PCR. Under this scenario, only $14 \%$ of the PCR reactions (3/28) displayed amplification plots (Figs. 2A, C, E, G, and Table 4). The predicted melting temperature for a WT template is $63.7^{\circ} \mathrm{C}$. However, the observed melting temperatures were 69.7, 92.2, and $92.2^{\circ} \mathrm{C}$, respectively (Figs. $2 \mathrm{~B}, \mathrm{D}, \mathrm{F}, \mathrm{H}, 3 \mathrm{~A}$ and $\mathrm{B}$ and Table 4). Furthermore, to test the method with another WT template, we evaluated the IDH1-TaqMan probe with a template from a diffuse astrocytoma IDH1-WT and observed that the melting temperature curve peaked at $65.6^{\circ} \mathrm{C}$ (Figs. $2 \mathrm{H}$ and $3 \mathrm{~A}$ and Table 4).

\section{Evaluation of melting temperature for IDH2 and H3K27/G34 TaqMan probe}

We tested the specific primers and TaqMan probes for IDH2 and H3K27/G34 using DNA obtained from a 
diffuse astrocytoma (II) - IDH1-WT, IDH2-WT, and H3K27M/G34-WT. Despite having obtained a good amplification efficiency and high-quality Sanger sequencing with the specific primers, the asymmetric real-time PCR with the TaqMan probes did not display any amplification plots nor melting curves (Table 4).

\section{Discussion}

The DMA of TaqMan probes in asymmetric PCR has been used to identify mutations in the PIK3CA, KRAS, $N R A S$, and BRAF genes in lung cancer, colon cancer, and melanoma ${ }^{17-19}$. Here, we tried to set up this melting analysis for the genotyping of pediatric astrocytomas by identifying specific mutations in the $I D H 1, I D H 2$, and H3F3A genes. As proof of principle, we used the IDH1TaqMan probe to identify the WT status of IDH1 in two different WT DNA templates (pilocytic and diffuse astrocytoma). We obtained four melting temperature values that ranged from $65.6^{\circ} \mathrm{C}$ to $92.2^{\circ} \mathrm{C}$. This broad variation in temperature is higher than the expected shift of $2-3^{\circ} \mathrm{C}$ if the mutation was present. Besides, only four out of 29 reactions displayed amplification of the DNA template, and amplification was observed only in one of the two technical duplicates of these four asymmetric PCR reactions (data not shown). As mentioned above, the successful amplification of the DNA template is an important parameter to do the melting temperature value more reliable ${ }^{19}$. Therefore, we conclude that the broadened values of the dissociation temperatures of the IDH1-TaqMan probe cannot be used as a reliable method for identifying a WT scenario. Albeit testing this TaqMan probe using DNA templates that harbor the mutations is still necessary, we speculate than the $\mathrm{KO}$ status of $I D H 1$ will not be identified by this analysis as the broad range of melting temperatures will mask the temperature shift induced by the presence of the mutation on the template.

Finally, when we used the TaqMan probes for IDH2 and K27/G34 in H3F3A, amplification plots were not obtained. Although more standardizations are required for these genes, we concluded that a significant variation in melting curves and long-time consumption makes this genotyping assay method not reliable nor efficient, at least for IDH1. Meanwhile, Sanger sequencing was faster and more reliable to detect the gene status in all the sequenced samples.

Here, we show that the DMA of TaqMan probes in asymmetric PCR was not reproducible nor reliable. We conclude that Sanger sequencing or alternative next-generation sequencing will continue being the gold standard genotyping method.

\section{Ethical disclosures}

Protection of human and animal subjects. The authors declare that no experiments were performed on humans or animals for this study.

Confidentiality of data. The authors declare that they have followed the protocols of their work center on the publication of patient data.

Right to privacy and informed consent. The authors have obtained the written informed consent of the patients or subjects mentioned in the article. The corresponding author has this document.

\section{Conflicts of interest}

The authors declare no conflicts of interest.

\section{Funding}

This work was supported by the grants of Hospital Infantil de México Federico Gómez-HIM/2017/104/SSA1420 and HIM/2016/096/SSA-1289.

\section{References}

1. Eguia-Aguilar P, Perezpena-Diazconti M, Benadon-Darszon E, de Leon FC, Gordillo-Dominguez L, Torres-Garcia S, et al. Reductions in the expression of miR-124-3p, miR-128-1, and miR-221-3p in pediatric astrocytomas are related to high-grade supratentorial, and recurrent tumors in Mexican children. Childs Nerv Syst. 2014;30:1173-81.

2. de Leon FC, Castro-Sierra E, Perezpena-Diazconti M, Gordillo-Dominguez LF, Santana-Montero BL, Rocha-Rivero LE, et al. Pediatric intracranial tumors. Bol Med Hosp Infant Mex. 2016;63:367-81.

3. Bhatia A, Pruthi S. Pediatric brain tumors: a different ball game. Semin Roentgenol. 2018:53:77-100.

4. Zong H, Parada LF, Baker SJ. Cell of origin for malignant gliomas and its implication in therapeutic development. Cold Spring Harb Perspect Biol. 2015;7:a020610.

5. Llaguno SA, Chen J, Kwon CH, Jackson EL, Li Y, Burns DK, et al. Malignant astrocytomas originate from neural stem/progenitor cells in a somatic tumor suppressor mouse model. Cancer Cell. 2009;15:45-56.

6. Louis DN, Ohgaki H, Wiestler OD, Cavenee WK, Burger PC, Jouvet A, et al. The 2007 WHO classification of tumours of the central nervous system. Acta Neuropathol. 2007;114:97-109.

7. Gupta A, Dwivedi T. A simplified overview of the World Health Organization classification update of central nervous system tumors 2016. J Neurosci Rural Pract. 2017;8:629-41.

8. Lousi DN, Hiroko O, Wiestler OD, Cavenee WK, editors. WHO Classification of Tumours of the Central Nervous System. Lyon: International Agency for Research on Cancer; 2016.

9. Board PDQPTE. Childhood astrocytomas treatment $\left(\mathrm{PDQ}^{\circledR}\right)$ : health professional version. In: PDQ Cancer Information Summaries. Bethesda, MD United States: National Cancer Institute; 2020.

10. Louis DN, Perry A, Reifenberger G, von Deimling A, Figarella-Branger D, Cavenee WK, et al. The 2016 World Health Organization classification of tumors of the central nervous system: a summary. Acta Neuropathol. 2016;131:803-20.

11. Watanabe T, Vital A, Nobusawa $S$, Kleihues $P$, Ohgaki H. Selective acquisition of IDH1 R132C mutations in astrocytomas associated with li-fraumeni syndrome. Acta Neuropathol. 2009;117:653-6.

12. Karsy M, Guan J, Cohen AL, Jensen RL, Colman H. New molecular considerations for glioma: IDH, ATRX, BRAF, TERT, H3 K27M. Curr Neurol Neurosci Rep. 2017;17:19.

13. Hartmann C, Meyer J, Balss J, Capper D, Mueller W, Christians A, et al. Type and frequency of IDH1 and IDH2 mutations are related to astrocytic and oligodendroglial differentiation and age: a study of 1,010 diffuse gliomas. Acta Neuropathol. 2009;118:469-74.

14. Cohen AL, Holmen SL, Colman H. IDH1 and IDH2 mutations in gliomas. Curr Neurol Neurosci Rep. 2013;13:345 
15. Wu G, Broniscer A, McEachron TA, Lu C, Paugh BS, Becksfort J, et al. Somatic histone $\mathrm{H} 3$ alterations in pediatric diffuse intrinsic pontine gliomas and non-brainstem glioblastomas. Nat Genet. 2012;44:251-3.

16. Sturm D, Witt $H$, Hovestadt V, Khuong-Quang DA, Jones DT, Konermann $\mathrm{C}$, et al. Hotspot mutations in H3F3A and IDH1 define distinct epigenetic and biological subgroups of glioblastoma. Cancer Cell. 2012;22:425-37

17. Botezatu IV, Nechaeva IO, Stroganova AM, Senderovich Al, Kondratova VN, Shelepov VP, et al. Asymmetric real-time PCR and multiplex melting curve analysis with TaqMan probes for detecting PIK3CA mutations. Data Brief. 2015:5:913-7.

18. Botezatu IV, Nechaeva IO, Stroganova AM, Senderovich Al, Kondratova VN, Shelepov VP, et al. Optimization of melting analysis with TaqMan probes for detection of KRAS, NRAS, and BRAF mutations. Ana Biochem. 2015:491:75-83.
19. Huang Q, Liu Z, Liao Y, Chen X, Zhang Y, Li Q. Multiplex fluorescence melting curve analysis for mutation detection with dual-labeled, self-quenched probes. PLoS One. 2011;6:e19206.

20. Livak KJ, Flood SJ, Marmaro J, Mullah KB. Self-quenching Fluorescence Probe. United States: United States Patent; 1998.

21. Kent WJ, Sugnet CW, Furey TS, Roskin KM, Pringle TH, Zahler AM, et al. The human genome browser at UCSC. Genome Res. 2002;12: 996-1006.

22. Ye J, Coulouris G, Zaretskaya I, Cutcutache I, Rozen S, Madden TL. Primer-BLAST: a tool to design target-specific primers for polymerase chain reaction. BMC Bioinformatics. 2012;13:134.

23. Needleman SB, Wunsch CD. A general method applicable to the search for similarities in the amino acid sequence of two proteins. J Mol Biol. 1970;48:443-53. 